\title{
O CHINÊS, O LOBO E A BRITADEIRA*
}

Tatiana Pellion

\author{
Psicanalista; \\ professora de \\ graduação em \\ Psicologia na \\ Université Paris \\ VII; doutora em \\ Psicopatologia \\ Fundamental pela \\ Université Paris VII; \\ psicóloga clínica do \\ Centro de Psicologia \\ e Psiquiatria da \\ Criança e do \\ Adolescente, do \\ Hospital Sainte \\ Anne. \\ Tradução: Raquel \\ Alencar Barreira \\ Rolim
}

RESUMO: A psicose na criança traduz uma posição confusa do sujeito no registro simbólico. A partir de um trabalho clínico com um jovem psicótico serão debatidas tanto a relação pulsional e a demanda dirigida ao Outro, como a necessária distinção entre pai imaginário, real e simbólico. Por fim, será tratada a construção do trabalho analítico, realizado ao longo do tratamento, para suprir a função paterna.

Palavras-chave: Outro, corpo, pai (real, imaginário e simbólico), pulsão oral, realidade.

ABSTRACT: The chinese, the wolf and the stone crusher. Child psychosis means that the subject has a troubled relationship with the symbolic. Through this case history of the clinical treatment of a young psychotic boy, we aim to examine the place of the drives in his relation to the Other and the Other's demand, the distinction that must be made among the imaginary, symbolic and real fathers, and then the role of the construction, in the course of the analytic treatment, of a way of making up for the paternal function.

Keywords: Other, body, father (real, imaginary, symbolic), oral drive, reality.

\footnotetext{
* Este texto foi apresentado na jornada de estudos do Espaço Analítico em Paris 'Impertinences de la psychanalyse d'enfant?', dias 19 e 20 de novembro de 2005, sob o mesmo título.
} 
"Não há nenhuma necessidade de ir muito longe em uma análise de adulto,

basta ser alguém que pratique com crianças para conhecer esse elemento que constitui o peso clínico de cada um dos casos que temos que manipular e que se chama pulsão."

(J. Lacan, 1901-1981/1964)

1 aiu!", me diz Augusto, um belo garoto de 6 anos, ao mesmo tempo que brincava entusiasmado com um caminhão-ônibus, sem passageiros, que se encontrava na minha sala. Ele pega uns bonequinhos, coloca-os dentro do ônibus e depois os faz cair do mesmo, dizendo: “Eles morreram!”... enfim, joga o caminhão. O menino repete este movimento diversas vezes, ao longo da primeira entrevista e fala: “Esse ônibus é doido!”, sem me olhar, imerso nesta atividade.

Augusto tem algumas dificuldades na escola. Ele está terminando o quarto ano do ensino infantil ${ }^{1}$ e parece ter problemas com o aprendizado. O garoto também apresenta problemas de relacionamento. É só, não tem amigos, “só no seu mundo", descreve a professora. Ele empurra os coleguinhas desde o maternal, o que na época fez a diretora e a psicóloga escolar aconselharem a mãe a procurar ajuda especializada. Sua linguagem é pouco compreendida, tanto no que diz respeito à articulação, como no plano da sintaxe que parece um pouco anárquica. Por esta razão, o garoto integra, há um ano, o "grupo de linguagem" organizado por dois fonoaudiólogos do hospital. Augusto me foi encaminhado, há algumas semanas, pela pedopsiquiatra da mesma instituição que o acompanhava e à sua mãe em um trabalho analítico, reiniciado com a partida da primeira psicoterapeuta. Augusto também já realizara três sessões de psicoterapia com outra psicóloga para um diagnóstico psicológico, cuja conclusão pareceu alarmante: “imaginário volumoso”, "prevalência de mecanismos fóbicos", "descontrole emocional e fantasmático". A equipe que o acompanhava, preocupada com o diagnóstico o encaminhou, em paralelo ao tratamento, para um projeto de hospital-dia.

Sua mãe compareceu à primeira consulta proposta pelo hospital, obedecendo sem entender muito bem em que consistia a demanda. A fala intermitente da mãe não tinha nenhuma pontuação. Sua linguagem demonstrava um jeito jovial, algumas vezes muito íntimo. Apenas as raras intervenções de Augusto, com o seu caminhão-ônibus, quebravam a enxurrada do discurso materno: "Caiu!”.

O trabalho realizado pela primeira psicoterapeuta pareceu ter sido objeto de muito investimento, sendo seu término bastante difícil, "principalmente pra

\footnotetext{
${ }^{1}$ Equivalente ao CP no ensino francês, considerando que o ano letivo europeu é de setembro a julho.
} 
Augusto”, precisou a mãe. Com relação ao desenvolvimento do filho ela descreveu que ele mamou durante três meses, andou aos 18 meses, mas começou a falar bem tarde; algumas palavras foram pronunciadas por volta de 3 anos, depois frases não muito bem construídas por volta de 5 anos. Nada de particular havia ocorrido durante a gravidez. Um eczema, desde as primeiras semanas, seguido de uma asma de bebê — que persiste ainda hoje — são sintomas assinalados, que o fazem ter um acompanhamento sistemático. A mãe refere-se, em primeiro plano, a uma possível separação entre ela e o pai de Augusto, além do seu consumo excessivo de álcool como fatos que tiveram importância na vida do filho.

O pai era construtor, trabalhava frequentemente no interior e podia se ausentar por longas temporadas (quatro a cinco meses), estando raras vezes em casa nos finais de semana. A mãe era zeladora, de origem portuguesa, logo, Augusto e ela moravam juntos no quartinho destinado a serviços de manutenção e limpeza do prédio. O garoto dormia quase sempre com a mãe, na ausência do pai, e o casal parecia atravessar uma grande crise. A mãe falava pouco sobre o marido, descrevendo-o como um homem ausente, que trabalhava muito - um trabalho difícil, feito com uma "britadeira”. Até então, o pai havia comparecido apenas uma vez à sessão. Quando perguntei a Augusto se ele tinha irmãos ele respondeu: "Sim, minha mamãe!” O emaranhado das gerações parecia se manifestar em sua fala.

A mãe de Augusto tinha muita dificuldade de me deixar a sós com seu filho. Durante alguns meses, tive que recebê-la duas vezes por semana na primeira parte da sessão. Na segunda parte, eu via Augusto sozinho. Apenas depois de dois anos e meio ela deixou-o sozinho a sessão inteira.

“Caiu!", me diz Augusto, mais uma vez, evocando o movimento repentino do seu caminhão-ônibus. Ao contrário do pequeno sobrinho de Freud (1920), citado em Além do princípio do prazer, que apresenta um movimento circular repetitivo do carretel, jogo do fort-da, Augusto marca aí um gozo sem ida e volta: “eles morreram”. Esse real puro será o centro de numerosas sessões. Durante o primeiro ano de tratamento, Augusto repetirá esta cena, sessão após sessão.

\section{0 ÔNIBUS}

Na segunda sessão, Augusto escolhe uma boneca russa que se encontra no canto da minha sala: "a mulher" ${ }^{2}$ — ele me diz — "fez cair o caminhão... e o caminhão quebrou”. Ele continua: “os personagens vão matar a mulher, pois ela queria quebrar o ônibus. Eu não gosto de brigas ele vai me devorar”. Sua mãe havia contado que ele tinha um problema com um coleguinha de sala que batia nele. Sobre esse assunto Augusto intervinha: "Os meninos, eles implicam

\footnotetext{
2 Em francês: la dame.
} 
comigo querem me comer não gosto disso... eu não me defendo, eu corro, vou ao banheiro, eu me tranco no banheiro, depois ele não pode se defender, aí ele vai me matar, ele não gosta de mim, eu não gosto dele... ele quer me matar, eu não implico com ninguém." Pergunto se ele tem amigos, e ele me responde que “o ônibus é doido... quando está embaixo, no chão, ele ainda é doido”. Augusto nos mostra: “ele faz assim, ó, nada a ver”. Ele faz voar o ônibus até a lâmpada do teto e continua: "o ônibus, ele vira doido agora, porque ele quer atravessar quando não tem mais..." - Augusto para, sem acabar a frase, pega a boneca russa e diz: "Ela precisa de um conserto, o ônibus tem que ser consertado, a mulher também vai consertar o ônibus."

Na terceira sessão, Augusto me fala sobre a escola: ele gosta principalmente da matemática e da leitura — mesmo sendo difícil - e bem menos dos exercícios de linguagem, principalmente quando tem que encontrar os verbos no infinitivo. A mãe pensa que ele é um pouco igual a ela, pois também não gostava muito das aulas de francês quando era criança, "era realmente um horror" descreve. No entanto, é em francês, a língua materna, que ela fala com o filho desde seu nascimento. Augusto me diz que o pai fala com ele em inglês e ele entende o que diz — vale ressaltar que o inglês não é uma língua utilizada por nenhum dos pais. A mãe constata que seu filho entende melhor quando é o pai que fala do que quando é ela: "Ele não bate nele” — precisa ela — só pelo olhar, Augusto imediatamente diz: "desculpa!"

Na verdade, o garoto ouve duas línguas: o francês e o português. Seu pai fala com ele em português, sua mãe em francês, sua avó materna lhe fala em português, etc. Esta última, a mãe da mãe, mora no apartamento em frente ao quartinho deles. Os outros membros da família moram também próximos e, durante o dia, todos se encontram na casa da avó do Augusto. O garoto referese a uma menininha chamada Maria, que é, na verdade, filha da sua avó. Ela também tem 6 anos, sendo apenas dois meses mais nova que Augusto. Os dois frequentam a mesma sala desde o maternal. A avó materna, que já tinha sete filhos, engravidou e casou com outro homem, que não era seu avô, mas também de origem portuguesa, dois meses após a gravidez da filha.

O avô de Augusto morava em Portugal, na casa da mãe dele; sua filha (mãe de Augusto) o descrevia como alcoólatra e violento. Ela se lembrava de cenas de quando era pequena e tinha que intervir para impedir que seu pai continuasse a bater em sua mãe. Seus pais, por fim, decidiram se separar no dia do seu casamento com o pai de Augusto.

As fronteiras entre as gerações são pouco claras na genealogia familiar de Augusto. Após três anos de consulta, quando propus ao garoto vê-lo no ambulatório hospitalar, por causa de uma reforma na minha sala do Centro Médico Psicológico (CMP), descobri que a mãe havia sido, quando bem pequena, paciente no mesmo 
CMP, assim como todas as suas irmãs. Pouco a pouco ela foi se lembrando da situação. A mãe de Augusto tem 30 anos e é a mais velha dentre as sete filhas. A menina que nasceu depois dela morreu aos 18 meses, gerando uma depressão em sua mãe, “que não pôde cuidar dela corretamente”. Cedo, ela também teve problemas de linguagem, assim como seu filho. Só falou aos 5 anos, razão pela qual não parece se inquietar com as dificuldades fonoaudiológicas do filho.

“Ele é doido!", me diz Augusto durante os próximos meses que se seguem. Ele manipula várias vezes o caminhão-ônibus, coloca-o de cabeça para baixo e o balança. O ônibus "vai à montanha”, dirigindo-se ao teto, depois ele desce novamente e "vai à eletricidade". Ao tocar na eletricidade, cai e não quer mais se mexer. Os outros personagens (seis ao todo) caem também, um depois do outro: “Ele não pode mais se mexer... o ônibus tá quebrado" — diz Augusto. Depois ele coloca os bonecos dentro, pega a matriochka e a põe bem em cima do ônibus. Augusto bate na boneca, pois, segundo ele, "ela faz barulho”. Ele quer colocar os bonecos no interior da "boneca-mulher" para fazer "mimi" (fazer dormir). Coloca então dois bebês no interior dela e tenta encaixotá-los, de maneira bastante confusa. Pergunto se ele também dorme, às vezes, como os bebês que estão no interior do ventre da mãe.

\section{O LOBO}

Na sessão seguinte, Augusto me diz não ter dormido muito bem, pois ele acordou muitas vezes à noite com dificuldade de respirar. Quando bebê, tivera muita bronquite, até que os médicos diagnosticaram asma. Ele acordava de noite, chamava sua mãe que lhe preparava a máscara de aerossol. Quando seu pai não estava, mãe e filho dormiam juntos. Augusto me diz que gostaria que seu pai estivesse presente no Natal. Pergunto se ele sabe por que seu pai não estava em casa; ele me responde que seu pai trabalha muito, que dirige caminhões para ganhar dinheiro. Depois, ele pega o ônibus, que se torna doido de novo, como da outra vez. Sua mãe propôs nos deixar e se encaminhou para a sala de espera. Ele recomeçou a brincadeira: “os outros estão mortos, teve um acidente, a mulher bateu nele (outro personagem), ele bateu nele, ela vai embora... por causa da mulher que bateu nela, ela morreu a bonequinha... ela faz a guerra... é a guerra...” Em um momento de destruição mortífera, Augusto colocou a boneca sozinha em pé: “ela é a única a dirigir o ônibus rápido... motorista de ônibus. Ela é má, ela faz a guerra, o ônibus tá vazio... todo mundo faz a guerra agora, ela morreu a boneca”.

Diante desse momento de desorganização, em que a pulsão de morte reina e em que Augusto se mostra bastante angustiado, faço intervir uma marionetepolícia e digo que ela poderia talvez colocar um pouco de ordem e acabar com a guerra. Para minha surpresa, ele agrega o policial ao jogo e diz: "você tem 
que fazer alguma coisa pra acabar com a guerra, é sua culpa, a guerra tem que acabar!".

Na volta das férias de Natal, recebi Augusto e sua mãe. ${ }^{3}$ Ela relatou de novo as dificuldades que atravessava com o pai do garoto. Eles brigavam muito; ela não aguentava mais suas ausências por causa do emprego e falava mais uma vez de separação. Augusto inicia uma cena com as marionetes: um lobo tem que comer uma bruxa, mas o policial cai. O lobo fica só na cena, saciado. Ele me diz que o policial parece um fantasma e ele bate nas crianças.

Logo que Augusto ficou só comigo, após a saída de sua mãe da sala, ele me perguntou onde poderia se esconder: “Eu estou morto”, dizia ele. Proibia-me então de olhá-lo: “Eu te proíbo de olhar pro Augusto você não pode olhar pro Augusto, eu sou Pinóquio.” E prossegue: “Augusto tá na casa dele, da mãe dele, ele saiu pra ver sua mãe. Augusto não está lá, ele foi olhar um cometa”. E me diz: "você se chama boca!”... e continua, "eu não sou uma marionete”.

O orifício ‘boca' pelo qual Augusto qualifica o lugar das sessões com bastante angústia vem assinalar a predileção da pulsão oral para ele. A cena da devoração na brincadeira, produção imaginária se sobrepondo, por conseguinte, com a realidade num Unheimlich (FREUD, 1919, p.147-188) marcou sem dúvida seu desaparecimento enquanto sujeito devorado, conduzindo a um puro real — " "eu estou morto". Podemos imaginar que este orifício era ao mesmo tempo o lugar da alimentação, aquele por onde ele respirava - comunicando com as vias respiratórias - como também o órgão da fala, aquele que é também do discurso ininterrupto do Outro.

\section{UMA BRITADEIRA}

Mesmo sendo as orelhas os únicos orifícios do corpo que não podem se fechar, ${ }^{4}$ Augusto tentava tapá-las. Ele parecia bastante solicitado, escutava barulhos, barulhos de "horror". No entanto, estas não pareciam ser vozes inventadas, pareciam mais com barulhos de alguém que iria atirar nele, ou maltratar. Ele me dizia: “as bruxas jogam feitiços, o barulho é de uma bruxa, eu vou morder”, em vez de dizer, eu vou tremer. ${ }^{5}$ O objeto 'barulho' passava a existir em si de maneira

\footnotetext{
${ }^{3}$ Aproveito para ressaltar aqui a importância da pausa no trabalho clínico com a criança inclusive quando houve uma indicação de terapia — é importante ver um pouco os pais, para entender o discurso que circula em torno e sobre a criança, pois é com este discurso que ele é confrontado todos os dias. É importante se desprender da maneira, a meu ver, "purista" e "ideal" de privilegiar apenas o lugar da criança e dos pais. A reflexão se impõe a cada caso, pois não há regra teórica estrita a esse propósito, o que seria, como afirma Maud Mannoni (1979), uma defesa do analista face ao imprevisto.

${ }^{4}$ Como desenvolve Lacan (1962-63/2004). Esta ideia também é desenvolvida por Annie Cordié (1987/1993), p 144.

${ }^{5}$ Em francês: "les sorcières jettent des sorts, le bruit c'est celui d'une sorcière, je vais cro (a) quer".
} 
isolada e com uma conotação de super-eu, angustiante e perseguidor. Era um barulho - o barulho que fazia inicialmente a boneca russa - que ao longo das sessões era esclarecido, um barulho que "o atravessava”, aquele de um fantasma, um fantasma com uma britadeira. Assujeitado ao olhar e, sobretudo, à voz materna, Augusto não podia esquecer o Outro e se desprender da sua posição de "receptor". ${ }^{6}$ Era bem mais um olhar para ele mesmo, pela instância julgadora, e falado por esse Outro que não se esgotava nunca, falado por um super-eu insistente, até mesmo malfeitor. O gozo deste parecia incessante. O barulho da britadeira era cada vez mais forte nas sessões, e presente às vezes no recreio da escola, como um retorno ao real de um significante que parecia ter grande dificuldade de se metaforizar. ${ }^{7}$ Augusto parecia entender o martelar das idas e vindas do instrumento do pai, o mesmo instrumento utilizado nos seus trabalhos no aterro. Este pedido de atenção, dirigido ao pai, na transferência, me induziu a lhe propor um encontro paterno, imediatamente aceito por ele.

Alguns meses se passaram entre a minha proposta e a possibilidade do encontro com o pai.

\section{AS TRIBULAÇÕES DE UM CHINÊS NA CHINA (VERNE, 1879)}

Augusto estava bastante calmo nesse dia e disse ao pai que gostava muito de vir me ver. O pai, aparentemente alcoolizado e, no início, um pouco apreensivo, abordou finalmente o assunto do seu trabalho, como operário, e de suas viagens a diferentes países. Mostrou-se incomodado por sua dificuldade de falar francês, explicando, ao mesmo tempo, que trabalhava muito para ganhar dinheiro e sustentar a família. Ele afirmava ter orgulho do filho, inclusive dos seus resultados escolares. Dizia também a respeito do filho: “Augusto é sem dúvida um pouco nas nuvens, no mundo da lua, às vezes ele quer comandar, mas quando eu lhe peço para fazer algo em casa, por exemplo, ele faz muito bem”. Informou ainda que, embora Augusto fosse o único filho do casal (sua mãe gostaria de ter outro), ele e sua esposa não tinham tido muito tempo de se dedicar ao filho.

O pai, no entanto, não parecia preocupado com as reações do filho, exceto sua dificuldade de se defender na escola. Augusto não é "firme... é meio mole", revelava o pai do garoto. Percebi que nesse momento o menino apresentava um comportamento curioso: uma postura desengonçada, como se tivesse um corpo elástico.

\footnotetext{
${ }^{6}$ Este ponto pode ser aprofundado com a leitura do notável trabalho de Alain Didier Weil (1995, p.333), sobre a construção do super-eu na obra Les trois temps de la loi, principalmente no capítulo "L'oubli inoubliable". O autor explica a nota azul "la note bleue", que é um ponto em que a sonoridade encontra o significante materializando-se.

7 É possível estabelecer uma relação com o desenvolvimento feito por Lacan sobre a foraclusão do significante, assinalando uma carência do efeito metafórico - "carence de l'effect métaphorique" (LACAN, 1957-58/1966, p.558).
} 
Novamente foi abordado o assunto, discutido no primeiro encontro com os pais. O pai de Augusto contou que quando morava em Portugal, conheceu a futura esposa na ocasião em que ela estava lá de férias. Na época, com 16 anos, não se sentia preparado para assumir um relacionamento sério. Foi então morar na França, à procura de trabalho e lá ficaram juntos por alguns anos. Tempos depois, Augusto nasceu. Ele "veio de repente", alguns meses após o nascimento do filho de seu irmão mais velho, que se chamava também Augusto. A avó do garoto queria muito que ele tivesse esse nome. O pai de Augusto foi criado em Portugal e sempre teve muita admiração por seu avô materno.

De repente, Augusto interessado pela história do pai, perguntou: "A gente tem bisavôs?" O avô paterno, bisavô de Augusto, foi quem transmitiu o sobrenome da família. Ele era segurança em uma barragem, "vigiava as coisas perigosas", era segundo o pai, "uma pessoa boa”, conhecida na cidade.

Nas semanas seguintes após a consulta com o pai, Augusto me fala de seu "medo de ser um fantasma”. Dizia que não queria morrer e ir para um buraco negro. No entanto, paralelo a essas angústias, emergiram também incontáveis questões. Meu paciente demonstrava grande prazer com a descoberta da forma interrogativa. Ele inventou um jogo que se chamava “jogo da matemática”, que durou vários meses. Em uma das sessões, propôs à sua mãe jogar também, sendo ela o mestre. O jogo consistia em procurar os números pares e barrar os números ímpares. As respostas erradas eram barradas e a solução correta para a interrogação tinha que ser encontrada.

Augusto se interessava, sessão após sessão, pelo saber do Outro; perguntava sobre o infinito e sobre os cálculos que ultrapassavam a potencialidade da calculadora. Tentava dividir um número por ele mesmo, o que resultava sempre no numeral um. Também fazia perguntas à sua mãe sobre o resultado de adições, de multiplicações. Quando sua mãe respondia de maneira supostamente errada, ele se irritava: "você tá vendo, você enrola, não tem o direito de fazer brincadeiras”. Ele inventou também o “jogo da conjugação”, no qual propunha que eu encontrasse a letra que faltava, por exemplo: o a de errada, o e de escritura, o a de matemática. Quando eu errava, ele me dizia: "Resposta errada, sua excelência!” Em uma sessão, Augusto me propôs um novo jogo, em que desta vez era eu quem devia responder a suas perguntas de múltipla escolha. A "boa resposta”, por ele designada, estava entre as opções sugeridas. "Que idade tem Augusto?”, "Qual o seu sobrenome?”, “Qual o nome da família do pai do Augusto?”, “Quantos anos tem a prima do Augusto (Maria)?” etc.

Desta forma, a intervenção nas sessões do "pai da realidade"8 claramente orientou Augusto a algo de novo, interrompendo o fluxo da pulsão vocal, dirigida

${ }^{8}$ O pai real (da realidade) oferece a possibilidade de se apoiar nele para um trabalho de construção do um pai imaginário. 
ao Outro, permitindo, sem dúvida, uma primeira "extração"9 do objeto corpo e possibilitando ao menino um emergente discurso. Essa intervenção parece ter tido um efeito de corte, dando ao objeto corpo status de objeto pequeno a. Nessa época, a escola decidiu que, além de continuar com as minhas consultas, Augusto iria ser reprovado no quarto ano escolar.

Augusto suportava cada vez menos as intervenções de sua mãe nas sessões. Ele dizia que não queria que ela interrompesse a sua fala. Às vezes ele tinha a impressão de que ela lia os seus pensamentos, pois dizia exatamente o que ele gostaria de dizer, sem lhe deixar tempo para se expressar sozinho.

Um dia, Augusto disse que o pai estava construindo um quarto para ele, no mesmo prédio, no final do corredor. Logo em seguida, propus um novo encontro com o pai. Este chegou bastante atrasado à sessão e, como na primeira vez, estava alcoolizado. Explicou que quase havia morrido no caminho, em um acidente de moto. Augusto suspirava, explicando que ele iria ficar muito triste caso o fato tivesse acontecido. Aproveitamos a oportunidade para abordar, na sessão, o tema da morte. O pai disse que era católico praticante e que ensinou o filho a fazer sempre o sinal da cruz: "Em nome do pai, do filho, do Espírito Santo, amém!" Augusto perguntou sobre o que aconteceu e disse que não acreditava em Deus. O garoto continuou o raciocínio: “antes não existia nem homem, nem mulher no planeta, né, pai?! Como é que se fabrica num homem e numa mulher um bebê?" Nesse momento, interrompi a sessão.

No encontro seguinte, Augusto pediu rapidamente à mãe que saísse da sala. Ele falou novamente do acidente de moto de seu pai e começou a desenhar uma estrada. Dizia: “Dói muito os acidentes dos pais, tem umas partes perigosas nas estradas que não são fechadas!” Augusto desenhou uma estrada cheia de buracos e "muito perigosa". Este incidente ocorrido com o pai o levou a se perguntar muito sobre a morte e a construir, durante várias sessões, um mapa. Ele iniciava por desenhar um circuito de moto com uma casa (espaço) em branco, no qual colocava um ponto de interrogação. Depois esboçava um circuito de diversos caminhos, com paradas e sentidos contrários (contramão). Ele media meticulosamente, com a régua, as distâncias para ir de um ponto a a outro b. Aparentemente, a notícia do pai "Eu quase morri!" — a moto dele havia se chocado contra um caminhão — angustiou e desorganizou a mente do garoto, mas também possibi-

\footnotetext{
9 Empregamos este termo no sentido utilizado por Lacan em nota de rodapé, em 1966, quando de sua elaboração do esquema R (LACAN, 1957-58). "D'une question préliminaire à tout traitement possible de la psychose”, ibid., p 553-554. Nota acrescentada em 1966. Logo, para que o campo da realidade seja constituído num sujeito, tem-se, segundo Lacan, que, simultaneamente à entrada do sujeito no campo do Outro, o objeto a seja extraído. O objeto voz-barulho tem, dessa forma, função de objeto pequeno a, sempre em atividade de objeto em torno do qual envolve a pulsão e não para de pedir satisfação. Ele é então extraído do campo da realidade.
} 
litou que ele se apoiasse no "quase” (naquilo que não aconteceu) para construir um mapa. Este acidente real do pai introduziu psiquicamente em Augusto uma questão topológica, que ele tentava representar e simbolizar em seu desenho. O mapa desenhado tentava, na verdade, articular diferentes lugares significantes para ele. Tinha a sua casa, a praia, o circo, o restaurante, o estacionamento para o carro, a casa da Star Academy, ${ }^{10}$ o Carrefour, o hospital, a polícia, placas de Parar e de contramão, estradas interrompidas, setas que indicavam caminhos, “direção Paris”, “direção Portugal” e "direção China”. A China, que não estava representada no mapa, assim como a escola de um lugar qualquer, passava a pertencer também a outro lugar barrado, que levava a todas as rotas, pontuadas com seus códigos e regras. Augusto, construindo seu mapa, passava a ter uma segurança, evitando perigos e voltando-se para outro lugar. Os habitantes desse outro lugar, "os chineses”, eram invisíveis, como o pai simbólico.

A vinda do pai real às sessões parece ter também provocado a construção da instância da função paterna. Ela permitiu, por outro lado, elaborar a representação do pai imaginário - aquele que sabe inclusive como ganhar dinheiro com seu trabalho. Augusto, que demonstrou ver no pai, desde a primeira sessão, traços de um ideal — tem que trabalhar para ganhar dinheiro — , quer hoje ser técnico de informática, para "consertar os computadores e ganhar muito dinheiro".

Fiquei sabendo, meses depois, que o acidente do pai aconteceu na mesma época em que sua mãe lhe anunciou que estava grávida do segundo filho. A castração do pai no real permitiu a construção de algo simbólico para Augusto, retirando-o de sua alienação e prisão ao discurso materno totalitário. Entre a primeira sessão, na qual o pai de Augusto revelou o desejo de sua esposa de ter outro filho e o decorrer do trabalho analítico, os pais do garoto fizeram outra criança. Esse fato, além de retirar Augusto da condição de único, o reposicionou na ordem das gerações. Maria não era mais sua irmã, seu pai e sua mãe tinham feito um bebê, uma irmãzinha - e Maria se tornara sua tia, por mais estranho que lhe parecesse. Augusto, que durante a gravidez da sua mãe teve alguns momentos de excesso alimentar, engordou bastante, investiu com imenso prazer no novo membro da família.

Anos depois, fui informada, em uma das sessões frequentes com o pai, que o motivo que levou Augusto e sua mãe a procurarem ajuda psicológica coincidiu com um grave acidente de trabalho do pai. Este enigmático acidente o impediu de se locomover por vários meses e, por causa de uma forte dor nas costas, ele pensava muito em suicídio. "Você não ia abandonar a gente!”, interveio Augusto, após a confirmação do pai sobre o fato. Desta forma, talvez a construção do mapa, através de uma identificação com o avô paterno, tenha também permitido

10 Programa televisivo de competição musical entre novos talentos, equivalente do brasileiro Fama. 
a elaboração de uma fantasia infantil: reanimar, fazer viver, reabilitar o pai e garantir a segurança.

Hoje, ${ }^{11}$ Augusto tem 11 anos e está no quinto ano do ensino médio. Tem uma irmãzinha de 2 anos e finalmente não precisou frequentar um hospital-dia. Em uma de suas últimas sessões, ele me disse que queria oferecer um presente de aniversário a seu pai — "Que tal um martelo para ajudá-lo no seu trabalho de operário?" Nesta mesma sessão aproveitei para falar do meu projeto de escrever sobre o trabalho que nós havíamos feito juntos, desde o início. Ele pegou a marionete do lobo e da bruxa e propôs contar-me uma história, a fábula do lobo e do carneiro. Neste momento, percebi que havia sido trabalhada a passagem de uma extração do objeto corpo próprio a uma inscrição simbólica do ideal, abrindo o cenário a um processo de sublimação.

Os barulhos esquisitos que viriam de um fantasma, como de um Playstation, passaram a ser representados por pesadelos. Desde então, ele gostava de propor ao longo das sessões o jogo da forca. ${ }^{12}$ Ele me fazia adivinhar palavras e se satisfazia me perguntando as letras que faltavam. Ele verificava, assim, que existem buracos na linguagem. O objeto 'barulho' extraído do corpo próprio, sob o modo da privação, tinha induzido a uma inadequação entre a pulsão evocada e o objeto barulho-voz.

O trabalho progressivo de deslocamento do lugar 'boca' ao lugar 'palavra' (discurso) foi, sem dúvida, facilitado pelo fato de ter sido feito na mesma instituição em que sua mãe foi atendida quando criança - lembranças revividas pouco a pouco. A confiança depositada pela mãe de Augusto na terapia vinha, de uma parte, do encaminhamento da escola e, de outra, do fato de este local de consulta já ter sido investido por ela, num momento de conflito com seus próprios pais. Isso ficou bastante claro quando, em uma consulta, ela mesma se propôs a retirar-se para deixar-me a sós com Augusto. A atitude só era possível porque ela se sentia em terreno conhecido. Ela mesma estava presa a um movimento de repetição, no qual o pai de Augusto, assim como o seu próprio pai, apresentava problemas de alcoolismo. Seu filho se sentia colado a ela, assim como ela mesma sentia-se colada à sua mãe. Assim, seus sentimentos só puderam se externalizar em meio às sessões, no lugar do Outro, que no caso era a instituição representada por mim. Ela permitiu que eu me apoiasse no pai de Augusto (pai real) provavelmente, apenas porque a instituição se fazia terceira para ela.

\footnotetext{
11 Texto redigido em 2005. Em 2008, Augusto estava com 14 anos e cursando o oitavo ano do ensino fundamental.

12 Em francês, jeu du pendu, que consistia em adivinhar algo e, a cada erro, contribuir para o desenho de uma potência.
} 
O mapa que Augusto desenhou, com todos os cruzamentos e seus obstáculos, representava, também, o caminho que ele fazia de casa à instituição ("hospital”), ou mesmo o trajeto dos numerosos encontros feitos aqui, como lugar onde se pode fundar, criar, construir a lacuna da função paterna.

Recebido em 26/9/2008. Aprovado em 4/2/2009.

\section{REFERÊNCIĀS}

CORDIÉ, A. (1987/1993). Un enfant psychotique. Paris: Seuil. (Points essais)

DIDIER-WEIL, A. (1995) Les trois temps de la loi. Paris: Seuil.

FREUD, S, (1919/1996). "L'inquiétant". Euvres complètes. Tome XV. Paris: PUF.

(1920/1996). “Au-delà du principe de plaisir”, in Euvres Complètes. Tome XV. Paris: PUF.

LACAN, J. (1901-1964/1981/). O Seminário, Livro 11: Os quatro conceitos fundamentais da psicanálise. Texto estabelecido por Jacques Alain-Miller; tradução de MD Magno. 2 ed. Rio de Janeiro: Jorge Zahar (Campo Freudiano no Brasil, 1998)

(1960-61). Le séminaire. Livre VIII. Le transfert. Paris: Seuil, texte établi par J-A Miller ; 1991.

(1957-58/1966). "D’une question préliminaire à tout traitement possible de la psychose”. Ecrits. Paris: Seuil.

(1962-63/2004). Le séminaire. Livre X. L’angoisse. Paris: Seuil.

(1964/1973). Le séminaire. Livre XI. Les quatre concepts fondamentaux de la psychanalyse. Paris: Seuil.

MANNONI, M. (1979). La théorie comme fiction. Paris: Seuil.

VERNE, J. (1879) Les tribulations d'un chinois en chine. Paris: Hetzel et Cie.

Tatiana Pellion

tatiana.tresmontant@wanadoo.fr 